\title{
Underemployment and the lived experiences of migrant workers in the hotel industry: policy and industry implications
}

\begin{abstract}
Although previous research has considered both high- and low-skilled migrant workers' career experiences in their host countries, this paper makes a unique contribution by presenting unmet career expectations of a cohort of professional migrant hotel workers in the UK. It injects a fresh insight by showing how professional hoteliers are 'allowed' to contribute to the success of the host country's hotel sector, but at the same time and by way of a backdrop, the state's immigration policies restrict their opportunities for career mobility, perhaps a case of robbing Peter to help Paul? Skilled migrant workers in this study encounter underemployment despite their qualifications and skills, resulting in career frustration. However, removal of immigration restrictions would permit them the flexibility to change occupations, often to employment opportunities where they can exploit their transferable skills. Empirical data were generated in the form of modified life histories, based on interviews that were conducted with Kenyan skilled migrant hotel workers. Examining the lived experiences of these workers presents a platform to highlight the role that structural factors play in inhibiting migrant workers' hotel career progression. This paper suggests ways in which hotel employers can tap into the workers' cultural capital in order to improve hotel business performance whilst making meaningful use of their qualifications and skills.
\end{abstract}

Keywords: migrant hotel workers, hotel career, underemployment, cultural capital, structural factors, Kenya, UK

\section{Introduction}

A prevalence of poverty, persistent unemployment and political instability in many fragile and less developed countries, have contributed to the increasing trend of international migration (Adepoju, 2000; Migration and Remittances Factbook, 2016; World Bank, 2016). This has contributed to a need for people to seek enhanced livelihood for themselves and their families (Ngoma \& Ismail, 2013). An avenue that has become feasible for many is through migration. This is exhibited by the movement from poor Global South countries to the richer Global North (Lewis, Dwyer, Hodkinson, \& Waite, 2015). Unfortunately, whilst human migration is perceived as means to overcome struggles for enhanced economic wellbeing, often it has resulted in unmet expectations where poverty manifests itself in other forms including career frustrations. Consequently, professional workers, originating from the Global South, are deprived of the opportunities to utilise their skills and work experience to the optimum.

Previous studies have primarily centred on the brain drain phenomenon, (Batista, Lacuesta, \& Vicente, 2007; Krasulja, Blagojevic, \& Radojevic, 2016) in particular, high skilled migrant workers abroad, whereas others highlighted experiences of migrant workers in low-skilled sectors (Anderson \& Ruhs, 2012; Rienzo, 2016). As such, this paper aims to plug the gap 
neglected by previous studies on labour migration by focusing on the career experiences of an unusual cohort of workers- Global South professional hotel migrant workers in the Global North. It maps the unmet career expectations of these skilled workers (in a perceived lowskilled sector) whose aim is to utilise their skills and professional experience in the UK hotel sector but our evidence suggests that rigid circumstances limit their ability to attain their career goals. Therefore, through this paper, we aim at stimulating debate amongst relevant public authorities and non-governmental agencies concerned with migrant labour in order to enhance recognition of migrants' workers cultural capital (skills, hotel professionalism and proficiency in the host country's language) (Bourdieu, 1986). However, Bourdieu provides a broader consideration of these to include accent, socially valued norms, language, skills and educational qualifications). Furthermore, we envisage that this work will contribute to a consideration of policy formulation that takes significant consideration of the offer that migrant workers bring to the host community, with respect to their qualifications, skills and work experience.

The paper commences by reviewing labour issues in the UK hotel sector, followed by highlighting the context of labour migration in the international hospitality industry. The third section explains the accumulation of the workers' qualification, work experience whilst in their home country. Following on, the methodology section describes the data collection method employed which is based on a modified life history approach and also explains the analytical approach undertaken. Findings and discussion of the experiences of the Kenyan hotel workers in the UK are explored and discussed illustrating these through the voices of participants. Finally, conclusions relating to the evident underemployment of these workers are drawn whilst also providing implications for the hotel sector.

\section{Literature review}

\section{Labour issues in the UK hotel sector}

In the UK, the significance of the hotel sector is felt in its employment terms as indicated by the UK Standard Industrial Classification as being amongst the 14 broad industrial sectors and in its broadest definitional terms, the $4^{\text {th }}$ largest employer (British Hospitality Association, 2017a). Nevertheless, for many decades attracting and retaining a qualified workforce has remained a significant challenge for the industry (Baum et al., 2016) given its poor status. It is characterised by; tendency for low wages; prevalence of unsociable working shift patterns; informal recruitment practices (Alberti \& Danaj, 2017); difficulties in recruitment and 
retention; predominance of younger workers, students, workers seeking flexi and part time work schedules and migrant workers (Baum, 2015). Unfortunately, the nature of employment demonstrated by these characteristics present are inherent evidence of forms of modern slavery (Robinson, 2013; Robinson, Martins, Solnet, \& Baum, 2019). Nonetheless, despite the poor image of the industry, it is surprising to have a cohort of professional workers that were available and willing to work in the sector. However, this is likely to be underpinned by the varied professional outlook of the hospitality industry that is context specific. Baum (2015) argues for a western-centric negative perspective of the hospitality industry whereas, a majority of the non-western countries have a vibrant perception of the industry. Therefore, this study follows a prediction by Devine, Baum, Hearns, and Devine (2007) that has been born out a decade later is the sector's labour shortages in the future. Consequently, as a means to tackle the labour and skills shortage encountered in the hotel sector, employers are drawn to depend on a substitute workforce (British hospitality Association, 2017b; Janta, Ladkin, Brown, \& Lugosi, 2011). This has the consequence of causing a disproportionate presence in low paid and temporary forms of employment by a particular group of workers - migrants (Mooney, Harris, \& Ryan, 2016).

McCollum and Findlay (2018) argue that the continued demand for labour in the sector, a pullfactor that is currently facilitated by freer mobility that bears a naturally strong positive effect on the flows of low-skill migrants. This is echoed by Anderson's (2010) argument that demand for migrant labour is stimulated by employers' perception that these workers exhibit a better work ethic than do local workers. However, the consideration is often an opening for labour exploitation, irrespective of the workers legal immigration status. This highlights a critical aspect of the sector which broadly suggests evidence of the contravention of the UN's protocols against human trafficking (UN,2004), given that restriction of movement of the worker is one of six indicators of forced labour, according to the ILO (2005) which he UN's protocols against human trafficking (UN, 2004). Interestingly, Robinson (2013) argues that the hospitality sector disreputably represents a significant proportion of the contemporary world's slaves. The workers remain silenced despite deplorable working and visa conditions. In the context of economic migrants, from Global South and who are perceived as 'good workers' and often equipped with cultural capital obtained from their countries of origin, the manifestation of postcolonialism in poor treatment of the workers should not be ignored. 


\section{Mobilisation of migrants' cultural capital}

Migration to Britain from Kenya is linked to the historical colonial ties (Okoth, 2003). Therefore, the consequences of the imperial and post-colonial connections resulted to a majority of Kenyans choosing the United Kingdom as a preferred work destination, given the status associated with working abroad. The assumption is that travel and exposure to a life in the West accords one an automatic recognition and status in the society. However, to migrate for economic purposes, it is important that individuals have skills and work experience that they can take with them to utilise in the host country. The cohort of Kenyan hoteliers in the study considered themselves well equipped for the international market.

The hospitality and tourism industry in Kenya makes a significant contribution to the gross domestic product (Okello, 2014). As such, capacity building in the hospitality and tourism industry has been a top agenda item for the Kenyan government. This was manifested through the provision of the reputable vocational hotel school in Nairobi, Kenya Utalii College ${ }^{1}$ (K.U.C) (Sindiga, 1994). The training institution was established with the mandate to equip workers with specialized cultural capital enabling them fit for the local, regional and global hospitality and tourism industry (Mayaka \& Prasad, 2012). Therefore, the existence and active contribution of the premium hotel training school, alongside other educational providers for the industry in meeting industry's skills demands, is an indication of vibrancy of hospitality and tourism careers in the African context.

Bourdieu (1986) considers cultural capital to be a combination of accent, socially valued norms, language, skills and educational qualifications. In the context of this study, cultural capital refers to migrant workers' skills, hotel professionalism and proficiency in the host country's language. Therefore, an individual considers the effort put in investing their cultural capital an important aspect in their lives. Bourdieu's cautions that capital is socially evaluated, suggesting that an individual's stock of capital is determined within a particular social and spatial context. Inasmuch as migrant workers are equipped with cultural capital that is valued in the host country, structural factors present in the host country may result in an undermining of the workers' skills. In a similar vein, assumptions are made that the rigorous training provided at the hotel school automatically positions graduates at employment levels

\footnotetext{
${ }^{1}$ Kenya Utalii College, established in 1975 is a prestigious hospitality and tourism training school in Kenya serving the African continent, under the Hotels and Restaurant Act, Cap.494, Laws of Kenya, replaced by the Tourism Act, 2011.
} 
commensurate with their skills and qualifications, locally and globally. However, this paper highlights the vulnerable positioning of skilled migrant workers originating from Global South into Global North labour markets, with a particular reference to the low-skilled hospitality sector, whereby structural factors often result in the workers 'experiencing forms of work exploitation (McDowell, Batnitzky, \& Dyer, 2009).

Another role performed by the hotel training institution is not only the ability to equip graduates with cultural capital, but also to create international institutional links. These links enable graduates to access scarce resources through belonging to a social network and/or institution (Bauder, 2005). K.U.C graduates serve the hospitality and tourism industries regionally and internationally. This makes a case for workers who have trained at the institution and migrated to work elsewhere, globally. In light of this, Currie (2016) recognises that migrant workers frequently use employment agencies to source work opportunities for them in the host countries, given the trust accorded to these agencies. The agencies play an integral role within the labour market to both the workers and employers in bringing the two together, although not necessarily matching employment needs of either party. However, whilst employers benefit from the services of employment agencies, it is possible that the expectations of the workers remain unmet. For instance, employers are supplied with skilled migrant professional hotel workers, who contribute to increased productivity of the hotel firms while at the same time it is possible that career prospects of these workers are remain unsatisfied.

\section{Context: Career immobilization of skilled Kenyan hotel migrant workers}

Kelly and Lusis (2006 p.836) acknowledge that 'forms of capital are embedded within an individual and do not get spent even when they are used'. Thus, when migrant workers obtain employment in the host country, it is envisaged that they obtain employment commensurate with their skills and qualifications. However, often there can be a mismatch between their skills and the type of employment they are able to access, resulting in underemployment of skilled migrant workers (Ressia et al. 2018). The ineffective utilization of workers' skills or qualifications has negative impacts on both the employee and the employer. Employers failing to tap into workers' optimal cultural capital are unlikely to obtain the full benefits of a skilled workforce, reducing workers' productivity. On the other hand, workers whose skills are suppressed and encounter difficulties in applying their capital, not only have their resources wasted but may also produce a sense of precariousness, indeed insecurity. The workers may experience workplace frustrations given the exclusion from fully utilising their cultural capital, 
irrespective of their skills and qualifications and often could bear a hindrance to their career progression. This is contrary to the significance of labour mobility in the competitive model of the labour market, which assumes workers are enabled to move to the most attractive jobs. In the context of the professional Kenyan hoteliers, the model does not depict their mobility as an automatic access to attractive jobs abroad. It is worth noting that labour exploitation is not limited to undocumented, smuggled or trafficked people (Wu, Guo, \& Sheehan, 2010) but can extend to legal migrant workers who often remain silent perhaps given their limited choices to speak out. Generally, this may be due to the dependence migrant workers have on a particular employer thereby reinforcing the dependence on the employers' goodwill for their legal stay to work in the UK.

Recent studies indicate that underemployment in Britain is still rife (Bell \& Blanchflower, 2019). In view of economic migrants, this suggests that individuals may invest in their human capital yet encounter difficulties in applying their cultural capital effectively. The skilled workers with professional experience are typical of workers described by Lucas and Mansfield (2010), as being generally of high quality yet positioned to work in low-waged sectors. Anderson and Ruhs (2010) cite labour and skills shortages as the primary reasons employers provide for relying on migrant labour as opposed to domestic labour. Migrant workers are willing to take on the jobs that occupy the low end of the skills spectrum. The workers display a tolerance of the apparent low image and precarious conditions within work places in the host economy perhaps with a long-term strategy that opts to trade off their professionalism for a western lifestyle. Nonetheless, the workers exemplify a clear disparity of hotel careers in the western and non-western contexts, where in the latter these type of occupations are popular due to high status linked with international tourism.

Thus, this paper does not aim to solve the human resource challenge faced by the sector, instead it highlights a category of workers who are viewed through the lens of 'modern slavery' and are characterised by 'unfreeness' (Munck, 2010) in the labour market. The paper maps the unmet career expectations of a cohort of professionally trained migrant workers whose purpose to work in an industry that has long suffered a poor status. The workers consider themselves their investment in cultural capital whilst in their countries of origin to have sufficiently equipped them with cultural capital that may reasonably be of value in their host country. Their aim is to utilise their skills and professional experience in the UK hotel sector but evidence provided by this study suggests that rigid circumstances limit their ability to attain their career 
goals whilst they encounter sustained underemployment relative to their training and work experience. Despite their negative career experiences and given their bound working visa conditions there a shift in the workers' mind set. The personal goal of career progress swings to the hope for an enhanced lifestyle for their family members when Home Office grants family reunification through the long-term route of obtaining permanent residency in UK.

\section{Methodology}

This paper draws on a wider study which considered the lived experiences of a total of thirtytwo Kenyan hotel migrant workers in the UK hotel sector. Sixteen interviews were conducted in Kenya (with participants that had returned to Kenya after a period of working and living in the UK) and the remaining sixteen interviews were conducted in the UK with Kenyans (still living and working in the UK at the time of the interviews). Table 1 provides a profile of the study's participants.

\begin{tabular}{lll}
\hline Participants profile & & \\
& Stayers & Returners \\
Age & $\mathbf{1 6}$ & $\mathbf{1 6}$ \\
$31-35$ & 2 & 6 \\
$36-40$ & 7 & 5 \\
$41-45$ & 1 & 3 \\
$46-50$ & 5 & 0 \\
$51-55$ & 1 & 1 \\
$56-60$ & 0 & 0 \\
$61-65$ & 0 & 1 \\
& & \\
Gender & 8 & 10 \\
Female & 8 & 6 \\
Male & & \\
& & Job roles in Kenya (Returners) \\
Job rolesin Kenya (pre migration) & Job rolesin UK & Entrepreneur \\
Head chef & Cook & Txecutive head chef \\
Executive Housekeeper & Room attendant & Receptionist \\
Restaurant Supervisor & Waiter/Waitress & \\
Food \& Beverage Manager & Receptionist & \\
Front Office Supervisor & & \\
& & \\
Occupation switch (Stayers) & & \\
Taxi Operator & \\
Restaurant entrepreneur & & \\
Student occupational therapist & & \\
Agency Chef in hospitals & & \\
Social worker & & \\
& & \\
\hline
\end{tabular}


The principal objective of this study is to examine trained hotel workers' career experiences in the UK's hotel sector against the backdrop of UK immigration policy and its influence in shaping workers' professional lives. Therefore, to understand the meanings and perception of the world as held by workers an interpretivist the study adopted an ontological and epistemological stance, that knowledge is created through the process of interpretation of perceptions, experiences and consequent action (Morgan \& Smircich, 1980). Crotty (1998) argues that interpretivists assume that meanings are created by human beings as they engage in the world they live in. Thus, according to Morgan and Smircich (1980), the subjective view of reality is through a conscious and creative condition of the human mind which gives meaning to surroundings and experiences. The empirical work employed a qualitative methodology, adapting a life history approach, albeit in its modified form. Life histories attempt to locate individuals in their overall life experience as well as in their broader socio-historical backgrounds within which they live (Faraday \& Plummer, 1979).

The epistemological foundation of the study is based on the understanding that narratives are a means through which an individual positions themselves as a subject, to provide a wealth of details of themselves. Similarly, the emphasis of life histories lies in the narratives and not on the explanation for the individual's behaviour (Weinberg, 2002). The aim is to understand the perspective of participants in the situation and to explore their meanings rather than discover the truths about the situtation. In doing so, it was envisaged that hidden meanings of migrants' daily experiences in the host country would be uncovered as they narrated their stories, as concerns have been about the marginalised in society, who have not been able or permitted to tell their life stories to others (Germeten, 2007). Thus, in response to the concern the significance of the study is seen through; a) its provision of an opportunity to the migrants to narrate their story to the world that might have remained aloof from migrants' experiences, and b) the ability of life histories to reproduce their views and social circumstances that may be difficult to reveal through other research methods. Furthermore, Germeten (2007) advocates life history as a research method due to its ability to communicate an unfamiliar reality, illuminating the lives of individuals to others.

Therefore, it was considered an appropriate approach to examine and bring to light the workers' experiences in a sector that has a predominance of migrant workers occupying low wage and low skilled employment. The stories from this cohort of skilled Kenyan hotel labour migrants 
reveal a fresh insight on migrants' lived experiences in the host country and outcomes of their careers.

Given the researcher's emic role in the study by virtue of holding an insider's position in the research, (whereby personal contacts with industry colleagues and by extension, professional relationships in the industry were at hand) and being part of a relatively small informal network of K.U.C alumni in the UK, recruiting participants was less challenging. Furthermore, rapport was built with participants as they considered the researcher as one able to understand and identify with their context. However, it is possible that the emic nature of the researcher is likely to have caused bias in the study.

Therefore, to minimise and account for researcher bias, it was necessary to adhere to researcher reflexivity (Lumsden \& Winter, 2014), through maintaining a research journal. Shaw (2010) notes that reflexivity is useful in its attempt to provide an open and honest research process. In exercising reflexivity, researchers endeavor to disentangle themselves from the complexities of their presence within the research and in order to produce authentic findings. This was important given that it was inevitable the researcher would bring their existing experiential knowledge as a professional hotelier and migrant worker in making sense of other migrants' career experiences.

The nature of the study focused on a specific and targeted group of people. Therefore, a purposive sampling strategy was deemed suitable. A snowballing technique was adopted to recruit participants whereby a few members of the group to be studied were identified. The identification of the interviewees was initially based on the researcher's personal contacts, stemming from an industry background and by extension, professional relationships in the industry, linking the researcher to participants. At each stage identified members were requested to recommend other participants as recommended by Lincoln \& Guba (1985). The selection criteria required participants to meet the following criteria: to be Kenyan, alumni of K.U.C, have migrated to work in the UK's hotel sector and, accordingly, have been holders of a UK work permit.

In life histories, participants are given the centre stage. Here, this was achieved by the researcher assuming a 'silent' role of attentive listening whilst noting down cue-phrases from the topics that emerged (Fontana \& Frey, 2003). Therefore, to evaluate a broader perspective of the likelihood of the migrants "childhood that might have influenced their career decision, 
the scope of the study allowed a specific focus- being that of their young adult life. This focus on the specific phases of the migrants' career lives was a necessary pragmatic alternative to addressing their entire life history. It was considered rational that parameters were set for participants to tell their stories, focusing on their post-secondary education to the present working lives (at the time of the interviews) and focus being their college education and work experience.

The interviews lasted about an hour and a half to two hours. Prior to the interviews being conducted, emails were sent out to recruited participants explaining what was expected of them at the interview. Information specifying the structure of the interview was provided. In as much as the interview is expected to be a conversation between the interviewer and interviewee, the researcher took the position of a passive interviewer. This paved the way for the participant to recollect and tell their stories with minimal interruption from the interviewer who only interjected to guide the direction and flow of the story in cases where participants struggled. Surprisingly, where it was necessary for the interviewer to interject in order to gather further information from the participants, it resulted in slightly shorter interviews in contrast to those where interjection was unnecessary. It would be expected that researcher interjections would result in longer interviews however, in the interviews, the more the interjections the shorter the interview period. This demonstrated the introverted nature of some participants in spite of the richness of their stories.

Participants' unavailability and geographical dispersion introduced a financial constraint to travel across the country to access other participants on a face to face basis. Out of the sixteen interviews conducted with stayers, six of them were via video Skype calls. As such, suitable arrangements were made with other participants who were spread out the UK. A similar step by step procedure as the face to face interviews in public spaces was followed, including note taking. In addition, the depth and length of the Skype interviews also dictated that it was essential to record them. Recording was done using Skype recording software. This was done in the format of mp3 and later transferred to the voice recorder for ease of transcribing. Face to face interviews with all returners were conducted in the capital city, Nairobi. In each interview, field notes were taken and transcribed following the session.

Whilst the interviews conducted were not aimed at being of a healing nature, at the end of the interviews, participants labelled them as being 'therapeutic' and 'conscious-raising', hence 
empowering them emotionally. A majority confirmed they had not been in such a situation where they sat back for up to two hours to talk about their migration experience in one sitting, recounting their career experiences. Nevertheless, it was an opportunity to reflect on their lived experiences as migrants, appreciating the journey until the present.

In the analysis of data, a thematic approach was adopted. The process of analysing the data produced a cluster of themes that was facilitated by employing the use of Nvivo software which was useful in producing a systematic and organised approach to group the emerging themes whilst synthesizing data. This followed a suggestion by Spencer, Ritchie, Ormston, O'Connor, and Barnard (2003) to order and synthesize data into subthemes and eventually into main themes. However, in order to identify primary themes from the set of data collected, the researchers relied on theory-related concepts, the key aim of the study, field notes and a priori knowledge of the researchers. Alongside field notes taken during field work, transcribing process was done immediately after life histories interviews were conducted so as to become familiar with participants' words that would be significant in theme identification (Creswell, 2009). Furthermore, listening, reading and re-reading of the audio recordings and interview transcripts was done to familiarize the researchers with the data. In organizing the data, it was rationalised to group the emergent themes around the workers' migration journey in a chronological order; in three broad topics, migrant's pre- migration, migration and postmigration journey. In seeking trustworthiness of the research and to create reader confidence in the accuracy of the findings, the researcher heeded Colaizzi's (1978) advice to conduct a member check in order to validate the findings. This was done by sending a findings report to the participants who were also asked to provide comments relevant to the researchers' interpretation of the data collected and analysed.

The voices represented in the findings section are in the form of vignettes and are a representative of the 32 modified life histories interviews conducted. The purpose of the vignettes are primarily for the purpose of this paper with an aim of illustrating the key themes that emerged from the data. 


\section{Findings}

Empirical findings are considered in this section in chronological order, firstly, demonstrating the workers' motivation towards a hotel career, followed by the accumulation of their cultural capital (training, skills, and work experience) whilst undertaking education and hotel training at the reputable K.U.C. The workers' career experience abroad is described and evidenced and finally the regulation of the state in migrants' labour mobility is also illustrated. 4 different vignettes under each theme are presented, totalling to a total of 16 vignettes that are used for this study.

\section{A hotel career preference}

The young workers considered testing out a hospitality course whilst they awaited places at the universities and when offers eventually came through, they declined and opted to continue pursuing hospitality courses. Similarly, it was not unusual for some that had already begun university studies to have to pull out of their degree courses to pursue a hotel career by way of enrolling at the hotel school.

Sugio passed well in her secondary national examination and when university places were announced in the following year as is usual practice in Kenya, she had been offered a university place to study a science degree, I was actually initially at Kenyatta University studying Botany. She also loved travelling, I have some wanderlust. She believed any course that was to get her out of university was good enough for her. She had not been looking for a career at the time she commenced her university studies. It was the natural thing to do after successful completion of secondary school but all she wanted was to travel. One year into her studies, the public university student riots occurred and they were suspended for 9 months. She considered this a perfect opportunity to seek a place at the hotel training school. Sugio approached the admission team at the hotel training school with a request for a place. Places were full and she was asked to apply in the following year. Sugio felt that was too much time idling and decided to do something useful whilst she awaited to apply for a place at the hotel school. She enrolled for a Certified Public accountant course in a local college in the city and got on with her studies. When the application process commenced, she submitted her application and was fortunate to get a place at the highly competitive hotel school. She continued with her accounting course which was useful at the hotel school given that Financial Accounting was one of the subjects offered in the Hotel Management course at the training school. Sugio did not regret giving up her place at the University to undertake hotel training as she enjoyed it and it did not waste her time out due to the prevalent student riots that were bound to happen over again during her degree course.

Upon completion of his secondary education, Chabiri qualified for a university place to study Forestry at Moi University. At start of semester, students went on strike, I debated within myself, my course appears completed before I even started it. Another offer letter came for him to study journalism and he debated once again, what are the chances of me opening my own TV station? Once students had completed secondary education, the desire was to swiftly move into a course without a waste of time waiting for university places, where there was likely to be delays in 
completing the course because of student riots. He later had an offer as an apprentice at a kitchen in a 3- star hotel in the city and did it for a year. He did so well that the chef encouraged him to apply to join K.U.C for a Food production course. Having had some work experience through the apprenticeship, Chabiri enjoyed his course, and given his outstanding performance he was exposed to other major hotels within African, UK and at the Caribbean before he finally returned to Kenya to run his own restaurant and mentor other young chefs.

Supita grew up in an agricultural town that had many tea plantations. Her parents worked in one of the tea factories which was managed by Europeans. As a child growing in a rural area, she was fascinated by foreigners. She was fortunate that her parents could afford to take her to the one and only local hotel in the town. Her dad boasted to them whenever they went to the hotel, when the directors of the company come, this is where they come for their meals. Supita started developing an interest in hotels because at this particular hotel, food was different to other local cafeterias she had been to previously, the staff were professionally dressed. However, Supita always wanted to be a doctor and hotel career was to be her second option. Unfortunately, she missed a place in the medical school by a few points and automatically went for her second option; a hotel management course at the hotel training school. She was lucky to get an offer at K.U.C where she did not regret her choice and has remained in the hotel industry, working in the $\mathrm{UK}$, at least up to when the interviews were being conducted.

Tula, grew up in the coastal region in Kenya where he was exposed to the hotel industry given its vibrancy in the region, because there are quite a number of beach hotels around our school. There were tourists all over, curio shops and the fun things you can imagine. So I got to know and experience them at that point in my life. With older siblings who had done well in school, he was encouraged by his father to do even better. So, at the end of his secondary education he also passed well and got an offer at the University to study Computer Science, that time it was not called Information Technology like it is today. Typical of student riots at public universities in Kenya, there was a student riot 6 months into his course and suspension given to students was 9 months long. Tula was against going home to stay and do nothing. Being exposed to the tourism industry, he had developed an interest of hotels, seeing tourists around his home town. So he decided to seek a place at the hotel training school. Tula was lucky, and he got an offer in the Food production course. He enjoyed the course, it was the most exciting thing that $i$ have ever done because I did well and topped in my class all through. It a wonderful run being there.

The conclusion to be drawn so far is that the drive towards a hotel career was due to the hotel training institution being favoured over university education, particularly due to the hotel training school's superior reputation over public learning institutions. This suggests the students' attraction to an institution where being a state corporation presented a definite time of completion of studies for the students over a poor image of public university's education (in the late 90's and early 2000's) where there were unnecessary study breaks due to student riots.

After this presentation of the various concerns and claims hotel training education over public university education the next section demonstrates the rigorous training offered at the hotel school providing a strong desire for a hotel career, even for the individuals who had qualified for university places. 


\section{Prestigious hotel school training}

Participants considered the hotel training received at KUC to have been rigorous and second to none according to the prestige awarded to the institution as the premium hotel training school across the continent. The vibrancy of the industry appealed to many young adults who considered a long-term rewarding career in the glamourous hospitality and tourism sector.

Kitangi was pleased with the news that she had secured a place at the prestigious hotel training school. Her parents too were pleased as they had even discouraged her from joining university where there would be significant delays in her tertiary education due to the student strikes. Kitangi had obtained good grades to be enrolled at the college and this made her confident whenever she went out for placements. She sensed that during the placements, students from other institutions were not highly regarded as Utalii college students. This enhanced her determination and confidence to succeed in the career that she had begun setting up. I have had excellent experience with my industrial attachments. In her class work, she also did well and when $4^{\text {th }}$ year rolled in she put in more effort and at the end of it, she emerged the top student, when it emerged that I was the best student that was exciting! I was like ok, I didn't expect it but cool that I was going to the UK. Through the partnership with the hotel owner that provided training and workplace opportunities for best students from K.U.C. At her work place the quality of training received was confirmed by colleagues and guests. She believed that the guests responded better to her than to her colleagues who had not received similar training, whenever there was an employee of the month kind of thing, I would always win it ... I would respond, That's normal... it's the training that I received.

An enticing thing at the college in my days was the monthly stipend of Kenyan shilling 240, remembers Sesema. She found the 2-year Housekeeping and Laundry course exciting and interesting because this is what she had dreamt of doing even before she completed her secondary education. It was a dream come true for Sesema. The placements we were exposed to provided me an opportunity to build up my hotel career very fast that by the time she approached her final year, she had an unpaid supervisory role at one of the 4 star lodges at Maasai Mara National reserve. Although whilst here, Sesema worked with a majority of staff that had not undergone training at the prestigious hotel school and were older workers. She worked diligently and from the theoretical knowledgeable she had obtained from class, it was a great experience to apply it at the lodge. She saw the opportunity to train at Utalii college as a reward for all the effort she put in school .Furthermore, having been raised in the village, folks in the rural places were against women working in the hotel industry as was considered an 'indecent' industry to expose oneself in. Often folks would tell my dad, we can't believe you have sent your daughter to Utalii College where she is going to train to become a prostitute. The rural folk did not appreciate the hotel industry given the negative stories they had heard. However, Sesema had promised herself that she would go back to the village to prove them wrong. I went back there and our neighbours at the village all came to see and talk to me. Upon graduation, Sesema was appointed a Housekeeping Supervisor at a 5-star global chain hotel in Nairobi. Here she climbed up the career ladder to the level of an assistant executive housekeeper prior leaving for UK where she has remained.

Edunju's interest at the hotel training school was little but after several class tests he passed them well and his interest towards a hotel career started growing rapidly, when we did the first few tests, my name came up because I became the star of the class. On graduation day, industry employers were present and Edunju was fortunate to be recruited as a laundry supervisor in a 
prestigious dry cleaning company. One day he was put on the test when a client brought a white linen jacket with a tea stain. The manager expected the team under the leadership of Edunju to remove the stain. I remember being summoned in the director's office and he reminded me, I brought you from K.U.C because you are professional. So there were expectations to deliver excellent results all the time. He worked at the prestigious dry cleaning for about 2 years before moving to academia. He was later appointed an assistant lecturer at K.U.C and at the same time required to undertake a teacher training course. At his time at the college there were several opportunities offering staff scholarships to study and train in the hospitality industry in Germany. Unfortunately, he did not get onto any of this. However, he built good work relationships at the college. When the UK based recruitment team went to the college to establish a rapport, Edunju was amongst the lecturers appointed by the principal to do a show round of the college and explain the curriculum to the recruitment team.

Following her college graduation Ndemwe, had two job offers, one at the coastal region and the other around Mt. Kenya region. Whilst the job offer at the coast was more attractive and lucrative, the hot humid climate put her off, and instead she accepted the offer at Mt. Kenya. The cooler climate appealed to her for personal health reasons. However, the salary was much lower but did not mind because she considered this a platform to develop necessary skills and build on her work experience that would be useful in preparing for employment abroad, the pay was mere peanuts but I knew I had to persevere because I needed the experience which would open my way to come to the UK.

Whereas there is cultural capital to be obtained in a training institution as K.U.C, there is some evidence suggesting that culturally in some societies, particularly rural people, have a negative perception of the hotel industry as being one that may be characterised by promiscuity. Nevertheless, given the popularity of K.U.C as a premium hotel training institution, even overseas based recruiters joined in to attract and recruit the specialised skilled workforce for the industry further afield.

Industry employers also played a significant role in the prestige awarded to KUC. The competitive nature of recruitment campaigns that took place in the run up to KUC graduation ceremonies demonstrated the industry's quest for a skilled workforce produced. It also suggests the industry's awareness of the value and quality of the graduates. Employment offers that were made to students prior to graduation whilst others received their job offers on the day of graduation suggesting the level and standards of training offered were apparent to employers. Furthermore, the graduates envisioned their career growth was not confined within the country, but there were prospects to work abroad.

\section{Migrant labour underemployment in the UK hotel sector}

Upon graduation, K.U.C graduates were positioned to work in prestigious establishments matching their qualifications in the hospitality and tourism industry in Kenya. As such the 
workers expected employment opportunities within the high-quality luxurious UK hotel establishments equivalent or at least similar to the Kenyan hotel establishments where they had had the opportunity to accumulate professional hotel operating standards.

Kafui considers her work experience at one of the 5-star hotels as restaurant supervisor in a fine dining restaurant as the best professional experience she ever experienced. Like many of her colleagues from the college, she started work immediately after graduation. Her graduation was on a Friday and the following Monday she was required to report to work. Standards of operation at the hotel were high, just what she had expected of such a prestigious hotel, standards were of the highest degree and it was a learning experience. We were exposed to international cuisines...the training was massive'. Besides the work, staff welfare was fabulous, the employer provided the good staff meals, transport to and fro work, the service charge was good and there was a staff medical cover. She once broke her leg at work and her medical cover took care of the medical expense. However, when she eventually gave up her job as a restaurant supervisor and moved to work abroad, she found the standards in the hotel she was positioned, lower than expected. Kafui remembers the human resources manager trying to convince her not to leave a pensionable job at a 5-star hotel to settle for a seasonal job abroad. But the wave to the channel island of Jersey, was so strong, it was a tide, it had to come, sweep and go. In the UK, Kafui was assigned a role as a waitress serving in a buffet restaurant. She found it difficult transitioning from a professional role, somewhere along the way I had to drop all my professional training, everything I had learnt was left at the airport.

Musa had been working at a 5-star hotel as Front Office supervisor. His role primarily coaching, leading and mentoring his team, and organizing the duty rota. When he decided to move to the UK where expected to fill a similar position, even though his official title was shift leader his primary duties were that of a hotel receptionist, and in most cases manning the reception by himself even without having been properly inducted in the role. Sometimes he was rota'd to work with his boss's daughter, who had just completed high school without any professional training and lor previous work experience. Musa felt quite frustrated but he had already committed to migrate abroad and although the thought of returning to Kenya crossed his mind, he remembered the he had made to his family left behind in Kenya about joining him in the UK.

Wabrayo expresses her shock the first time she got to the UK because the impression she had of the UK while back in Kenya did not live up to her expectations up. The hotel she arrived at to work was different to what she had been used to previously in her home country. She and her colleagues were accommodated in a live-in accommodation and sharing facilities was the norm, we were sharing bathrooms and toilets, it was like in a boarding school back home. Her work permit had stated that she was allowed to work as a housekeeping supervisor, but this did not happen, in my induction I was assigned 14 rooms to clean. It dawned on me that I had to work as a room attendant and this did not appeal to me at all. Wabrayo, like many of her colleagues could not gather courage to complain to her employer about her role. She considered her salary, although not so great compared to the job she was assigned, to be much better than what she was earning whilst in Kenya. Wabrayo complained of being regarded as an unskilled worker by her work colleagues and this frustrated her further at her work place. She complained that she worked with other foreign workers from the EU, who sometimes, did not even understand English and had no professional training, and still they were the supervisors. We had the professional training yet we were the attendants! 
Bobo's story was no different, he considered himself being misused at his work place. He was quite frustrated that with all the professional training he possessed it was neither appreciated nor put into good use at his place of work. Bobo felt at loss having worked as head chef in one of Nairobi's 5- star hotels, where he commanded a brigade of kitchen staff, but here he was in the UK performing junior roles, I could even clean the floors. Bobo considers the only benefit of having migrated to the UK, is the opportunity to have been abroad, as far as I'm concerned, my ego is brushed because I have been to London otherwise there is nothing really to tell story back home. It is interesting that what Bobo sums as his experience abroad is as having 'been' but does not narrate it as having 'worked' in the UK'

According the life histories, employers often applied double standards on the migrant workers at their work places. The workers even though qualified for supervisory and managerial level hotel jobs, the roles assigned to them were non- supervisory and non- management in nature. This demonstrated the employers' disregard of their previous qualifications and skills. However, at the same time given their professionalism the workers were required to train other work colleagues who had been easily absorbed in the hotel industry despite the lack of both hotel professional and language skills. The workers considered it unfair treatment at work especially because they were skilled professionals, yet recognition of their qualifications and skill was as and when it suited the employers.

Given the robust hotel training that Kitangi had received she expressed her frustration of her professionalism being only considered whenever it was favourable to the organization. This was in addition to the already low ranked position she was assigned. For instance, whilst in her role as a hotel generalist, Kitangi was sometimes called upon by the manager to train her colleagues who had inadequate English language skills. Furthermore, she was also expected to provide support to her colleagues who had little to no hotel work experience on their hard and soft skills required the role they were performing, I really wasn't interested in the industry anymore, in the UK because it was quite challenging and frustrating to work with people who hadn't been trained.

The vignettes above take into account the level of hotel training that the workers underwent, and is no surprise that they anticipated employment commensurate with their skills and work experience. Previously in Kenya, the were ranked at managerial positions in high- end hotels in contrast to the UK, where they held non-managerial roles and were not only positioned to work in the lower ranked positions of the hotel establishments but in small owner-managed independent hotels.

The workers considered their cultural capital in a foreign labour market as a conduit for career progression. However, this was looked down upon by the receiving society, where in many 
instances their qualifications and skills were perceived to be inadequate. Work colleagues who were migrant workers themselves, albeit with freedom of movement in the UK, further frustrated these professional hoteliers at the workplaces by a tendency to devalue their skills and previous work experience.

\section{Regulatory constraints}

The histories showed that sponsorship by UK employers was a mandatory legal requirement for non- EU workers seeking permission to enter the country. The immigration law bound the workers to the one employer that had sponsored their work permit. The legal immigration arrangement allowed the migrant workers access to the labour market, however on the dark side of it, the workers were denied access to progress their hotel career as they were tied down to the one employer at a time (usually until a period of 5-years of legal stay in the UK in order to obtain permanent residence in the UK). The cohort of professional hotel migrant workers endowed the industry with their skills, yet they remained, to some extent, exposed to exploitation by the system and unprotected by the law.

Inasmuch as Bogo had exposure to the British culinary and for which she is grateful, she strongly felt that she would never look back and go back to work in the UK. This mainly because as much as she would have liked to grow in her career as a hotel chef, she hit a 'glass ceiling' with her employer due to the work permit conditions that did not allow her to change employers, with a work permit, I would never move from one place [employer] to the other, not even for training, She considers to have had a constrained life and career in the UK, being on a work permit was a life in a cage. Bogo felt restricted and had no chance to enhance her career. She could not understand the restrictions on working under a single employer even with obvious opportunities like training or working in sister hotels, there was a sister hotel in a different town and I wished to go for some exposure there but I just could not. Bogo considers this a huge loss to the businesses where staff on immigration restrictions cannot move around within an umbrella company, yet this would be beneficial to the organization. Eventually, Bogo returned to Kenya as she believed that it was only in returning to her country that she had the chance of progressing her hotel career. At the time of the interview, she was working with a premium business that had organizations in many countries, I'm now expanding my career to the premier business world and could not look back to go to UK.

As a family man, Njoni feels that the UK immigration treated him so harshly that he doubted his move to the UK. He started his work at the channel Island, Jersey where the immigration law was slightly different to the law on mainland UK. This is because when working for an employer in Jersey, he and other Kenyan hotel workers were allowed to work for only 9 months in a year given the seasonality of hotel business in the region. He considers this to have been time and resource wasteful because it appeared that for the 9 months he spent in Jersey working he was working towards earning his flight ticket to Kenya and hopefully if his employer wished to recall him for subsequent season, then he also had to save up to have a return ticket back to Jersey. He was living in uncertain times, it was frustrations after frustrations, yet I am father and my family 
looked up to me to provide. Once Njoni arrived for work on Jersey Island and got to understand the law he did not wish to return in the following season. Time spent in Jersey did not country towards qualifying for permanent residence in UK. Once he had done two seasons, he returned to Kenya and through the Kenyan hotelier professional network in UK he actively sought employment. It proved less challenging for him given that he was considered to have had some experience in UK. Njoni was able to secure employment on mainland UK. This was a loss to his Jersey employer. During his 3 months' time off work which Njoni had to spend in Kenya as he awaited approval of return by Jersey employer, it was not a surprise to him that his employer sent him several requests to return for the following business season, given the professionalism he had displayed in his role as a cook., the head chef had noticed the professionalism with the group of us Kenyans from K.U.C. Eventually, Njoni was eligible for permanent residency given his 5 -years stay on mainland UK. He then qualified for family reunification, although not without difficulty, it was a real struggle with Home Office to allow my family to join me.

On Umaka's work permit similar to those of his Kenyan hotel migrant colleagues, the statement was clear that he had no recourse to public funds. This did not mean anything to him because in Kenya, at the time, the social welfare was non-existent. Umaka knew that to earn a living he had to work and if no work was available, he would have to depend on the goodwill of his extended family but not the government. Furthermore, he was prepared to earn a living from his work, $I$ was prepared to sustain myself financially. Umaka's family situation was slightly different to those who had left their families behind in Kenya. He and his wife met and got married in the UK after which they started a family. In terms of family reunification this was less challenging as they did not have to go through the visa application process as their children had been born in the UK. When his children were born, he and his wife had already obtained permanent residence which automatically led his children to being considered 1 UK permanent residents. A choice that Umaka was happy to have made, I came to a decision of bringing them up here. Having grown and been brought up in Kenya, Umaka knew the differences in lifestyle and his choice was to raise his children in the UK, although the immigration was tight on us because we couldn't change our jobs even when we had to work under very hard working conditions, we had to hung on so that we could give our children a good start in life.

Kagita considered herself an oppressed mother who had been denied access to her children in the channel island of Jersey where she worked. She did not understand the reason of being granted a work permit as a mother but her children denied the same. Her plan was to move to work in the UK and her family join her immediately. The family situation got really straining when she fell pregnant. The immigration law in Jersey varied from that of mainland UK. Pregnant migrant workers were not allowed to work in Jersey, the work permit had specified. Therefore, to make ends meet, Kagita tried to conceal her pregnancy from the employer until when it was close of business season. I went to Kenya, really exhausted, had my baby and so determined, I left behind my 3- month old baby with my mother, I was dying inside of me. The whole process of family reunification was long and daunting. It meant that she had to leave her young children for nearly two years. Kagita had to move out of the employer's live-in accommodation and get a family house which further strained her income. Even after securing a family living space, the childrens' visas were denied by Home office on three occasions. I had to go to the tribunal. It pained me that I came here in the UK as a hotel professional but that meant being separated with my children, that's inhumane! She hoped that no one had to experience what she had to endure. It was a financially and emotionally draining journey for the family to be reunited, I got into debts which thankfully I have been able to clear. After a long struggle Kagita, her husband and children were eventually reunited. 
The vignettes above reveal a double edged sword of the immigration system, given that it provided the workers legal entry to the country but on the dark side of it, the workers were denied the path to a successful hotel career that they had envisioned. This is as a result of the boundedness to a single employer. The absence of a provision for the workers to exercise a freedom of employer choice exacerbated the workers exploitation from an organization to a state level. The workers considered themselves to be law-abiding but believed they were victimized by the same law that was there to protect and serve them. Nonetheless, their unmet career expectations left them dispirited to remain in the hotel industry but willing enough to hold on to living and working in the UK as trade-off for a more privileged lifestyle in the UK for themselves and their families.

Regardless of the career frustrating circumstances they were presented with, the workers remained loyal to their employers in spite of the annual worker permit and visa renewal, which opens them to work place exploitation, until such time when they no longer required the favour of their employers as their work permit sponsors i.e. when they obtained permanent residency.

\section{Discussion}

The discussion of the study revolves around the unheard life histories a unique cohort of migrant workers in the UK low skills sector. They are a group of workers equipped with cultural capital, specifically, professional qualifications, work experience, language and a positive attitude and prepared to work far away from the comforts of their homes. They sought to work abroad with the inspiration to enhance their hotel career. They had high expectations but unfortunately these career expectations were unmet upon arrival at the host destination. However, the workers were able to put up with the reality of what they found at their workplaces in a manner suggesting that had accepted to trade off their hotel career aspirations for a better lifestyle in the UK.

\section{Motivation towards a hotel career}

Findings reveal differences between aspects of a hotel career in the developed and developing nations (Baum, 2015). In the former, hospitality careers lacked status, whereas in the nonwestern contexts, the hotel industry is vibrant, and therefore, appeals to many potential workers. Most of the participants revealed their preference for hotel school training instead of 
pursuing a degree course at the university. As such, juxtaposing a hotel career against other careers which would be developed over years spent at university, shows a clear preference for hospitality and tourism careers which might have been purported to lead to higher quality lifestyle. The environment to which individuals are exposed can also play a role in influencing individual choices. For instance, individuals who grew up surrounded by tourism activities and/or host-guest interactions inclined them towards a hospitality career.

\section{Accumulation of cultural capital}

The reputation of the hotel school was paramount in the decision-making process of pursuing a hotel career. The pace set by the hotel training institution in producing a well-trained workforce for the hospitality and tourism industry was an enticement to many high school leavers. As such, following the robust and rigorous hotel training received, graduates developed a positive approach to working in the hotel industry. In the Kenyan context, the hospitality and tourism educator partnered with the industry in the development of specialised skills and deployment of the workers. Consequently, a majority of the hotel school graduates obtained employment in the high branded luxury hotels either upon completion of their industry placement and before graduation or on the actual day of graduation. The industry was eager to absorb graduates into the labour market immediately and provided a positive perception to fresh graduates who had the aspiration of carving out a career in the hotel profession.

Besides, obtaining professional qualification and training at the hotel training school, the college also stood in the gap of the graduates obtaining employment. Locally and globally, the industry was confident of recruiting its workers from the institution given the high quality of the workforce. In the Kenyan context, even during graduation ceremonies, industry employers were present to conduct recruitment campaigns. The workers capability is illustrated by the pattern of the graduates' entry position at supervisory and rapidly rising to middle level management positions. Akin to the notion of high calibre workers, internationally, UK-based recruitment agencies also were not left behind in recruitment of professional workers for assignments abroad. Bauder (2005) acknowledges that social connectivity is having the ability to access scarce resources through belonging to a social network and/or institution. Therefore, the workers relied upon the social connectivity of their Alma matter to obtain employment abroad whereas employers were certain of high calibre workforce from the institution. 


\section{Exploitation of professional migrant hoteliers in UK}

According to McDowell et al. (2009), employment opportunities in the low-waged sectors are predominantly reserved for disadvantaged groups in the society. Although, possibly not structural factors such as level of education attainment or poverty levels, which would socially exclude the cohort of Kenyan migrant workers they still experienced a system exclusion, thereby disadvantaged in the labour market. In spite of their level of skills and experience obtained locally in 5- star hotel establishments the professional hoteliers formed part of the labour force within the low- skilled industry in the UK. The findings reveal a disconnect between migrants' cultural capital considered relevant for the UK hotel sector and the positioning in a foreign labour market that fosters their vulnerability as bounded workers, exemplifying unfree workers. This resonates with Bourdieu's (1986) understanding of the significance of migrants' cultural capital (language, education, qualifications, and work experience) which are considered necessary to have the potential to yield positive labour market outcomes. Instead, the workers had limited alternatives and pushed to precarious employment (at least up to when they were no longer subjected to immigration control). Nevertheless, the professional migrant workers remained accepting of the condescending treatment from other workers, whom they considered less qualified and unskilled. Yet, employers appeared to favour the 'unprofessional' over the professional Kenyan workers despite the superior competencies of the latter cohort. This results in under skilling, reduced motivation in organizations as Ressia found was the case in Australia.

\section{Oppression by state immigration regulation}

The hotel sector and the UK immigration policies are encountered as institutional barriers by the Kenyan hotel migrant workers to hotel career progression. From a legislative perspective, while it is necessary to have in place an immigration regulatory framework in order to safeguard boundaries from any anomalies (Castles, 2000), for example irregular migrants, Anderson (2010) argues institutional factors such as immigration law and policies have often produced precarious conditions for legal migrant workers. The immigration policies introduce the paradox of an institution that facilitates geographical mobility of migrant workers (from their countries of origin), yet immobilises their career growth whilst in the host country. 
Conditions of the working visas available dictated that workers remained in (under) employment with the one employer for the period covered by the work permit. This implied that the workers did not have the flexibility to change employers and as such remained attached to a single employer regardless of work-place challenges they may have encountered for fear of deportation. This further exacerbates the workers' career frustrations, as these barriers take control of the workers' geographical and /or career mobility, given the lack of institutions to support them in the host country.

The attainment of 5- year legal working in the UK was a significant aspect of the workers' lives abroad. It provided the workers the eligibility for permanent residency. This gave the 'freedom to exercise vocational mobility, geographically, career wise, and in some cases, family reunification. However, reuniting with the family members left behind in Kenya also proved financially and emotionally challenging. Nevertheless, a majority of the workers were eventually reunited with their dependants (spouses and children), but only as long as the children were below the age of eighteen.

\section{Conclusions and implications}

The focus of this paper is the unsatisfactory labour market outcomes of migrant workers' particularly in the low - waged industries such as the hotel sector, irrespective of the cultural capital they possess. This results in sustained underemployment and has a negative impact on their career progression. The study also highlights the impacts of structural factors such as the immigration law that transforms migrant workers into bonded individuals, with no room for negotiations about what they may offer in terms of their skills and work experience. Therefore, this leads to the conclusion that their underemployment is wasteful and counterproductive

This paper looks to provide insights and builds on debates on the underemployment of professional and skilled hotel migrant workers, caught between a varying western and nonwestern social status view of the hotel sector. Given a high social standing of the hotel profession in their country of origin, the cohort of workers had purposed to migrate to the UK in order to advance their hotel career. Therefore, the findings of this study seek to build on the work of labour migration by incorporating the experiences of skilled labour migrants in a sector that has a western-centric social construction, being that of a low status. 
Labour migrant studies have previously focused primarily on the western context and on migrants with freedom of movement. Mobility freedom is atypical in the global south-north labour migration whereby workers are not only faced with non-recognition of their in the host country, rigid institutional factors also have a role in inhibiting their career progression.

The conclusion drawn from the findings points to some of the limitations of human capital theory which assumes a return on investment on individuals' educational qualifications, training and professional skills. The expected returns on their human capital investment may be impeded by structural factors that in the case of migrant workers, result in them facing sustained underemployment in the host country.

Structural factors in the form immigration regulatory frameworks may restrict the geographical mobility or flexible working arrangements of labour migrants, hence, positioning the workers in precarious work environments ultimately hindering workers' aspirations. The lack of optimal utilisation of migrant workers' cultural capital results in their underemployment. This has an impact on both the worker and employer a) where firms do not tap fully on workers skills, qualifications and work experience, they do not obtain the full benefits of their workers, and $b$ ) there is a less likelihood of workers achieving their career-led goals.

Based on the recent on-going debate on Brexit and its aftermath, it is an important consideration for the industry, given that it demonstrates that precariousness in the context of migration, is not only problematic for migrant workers, but can bring about undesired outcomes for a country's labour market.

\section{Limitations and future research directions}

The study's sample size was not only small but did not include a varied cohort of participants. Taking into considerations perspectives of employers and recruitment agents would have been necessary to obtain wider knowledge and possibly a balanced outlook of the phenomenon under study. There are possibilities that the emic nature of the researcher is likely to have caused bias in the study. However, to reduce bias, researcher reflexivity was ensured and a member check conducted to ascertain accuracy and trustworthiness of the study.

In the face of political changes in the UK, as with Brexit, it is necessary that investigation is conducted to find out any additional recruitment challenges to be faced by the hospitality 
industry, more severely experienced after 2020, after the UK is no longer part of the European Union.

This paper speaks to both policy and practice with respect to migrant labour in the hospitality industry. It highlights some of the gaps that may emerge when the two are not addressed in consort, notably the intersection of immigration law, employer needs in the hospitality industry and the individual career aspirations of migrant workers. Future stakeholder engagement in this area must address all three dimensions in an integrated way in order to gain maximum benefit for all parties. Thus, to begin with a , a study exploring ways in which employers may benefit from employing a skilled migrant workforce, is necessary so that migrant labour s does not only offer short-term solution but has long term negative implications for the hospitality sector.

\section{Declaration of interest statement}

No potential conflict of interest was reported by the authors.

\section{References}

Adepoju, A. (2000). Issues and Recent Trends in International Migration in Sub-Saharan Africa. International Social Science Journal, 52(165), 383-394.

Alberti, G., \& Danaj, S. (2017). Posting and agency work in British construction and hospitality: the role of regulation in differentiating the experiences of migrants. The International Journal of Human Resource Management, 28(21), 3065-3088.

Anderson, B. (2010). Migration, immigration controls and the fashioning of precarious workers. Work, Employment \& Society, 24(2), 300-317. 
Anderson, B., \& Ruhs, M. (2012). Reliance on migrant labour: inevitability or policy choice? Journal of Poverty and Social Justice, 20(1), 23-30.

Batista, C., Lacuesta, A., \& Vicente, P. C. (2007). Brain drain or brain gain? Micro evidence from an African success story.

Bauder, H. (2005). Habitus, rules of the labour market and employment strategies of immigrants in Vancouver, Canada. Social \& Cultural Geography, 6(1), 81-97.

Baum, T. (2015). Human resources in tourism: Still waiting for change?-A 2015 reprise. Tourism Management, 50, 204-212. doi:http://dx.doi.org/10.1016/j.tourman.2007.04.005

Baum, T., Cheung, C., Kong, H., Kralj, A., Mooney, S., Ramachandran, S., Dropulić Ružić, M., \& Siow, M. (2016). Sustainability and the tourism and hospitality workforce: A thematic analysis. Sustainability, 8(8), 809.

Bell, D. N., \& Blanchflower, D. G. (2019). The Well-being of the Overemployed and the Underemployed and the Rise in Depression in the UK. Journal of Economic Behavior \& Organization, 161, 180-196.

Bourdieu, P. (1986). The forms of capital.(1986). In J. Richardson (Ed.), Handbook of Theory and Research for the Sociology of Education (pp. 81-93). New York: Greenwood press.

British Hospitality Association. (2017a). The economic contribution of the UK hospitality industry Retrieved from http://www.bha.org.uk/wordpress/wp-content/uploads/2015/09/Economiccontribution-of-the-UK-hospitality-industry.pdf. Accessed on $1^{\text {st }}$ November 2019.

British hospitality Association. (2017b). Labour Migration in the Hospitality Sector. Retrieved from https://www.bha.org.uk/wordpress/wp-content/uploads/2017/05/BHA-EU-migration-finalreport-170518-public-vSTC.pdf. Accessed on $1^{\text {st }}$ November 2019.

Castles, S. (2000). International Migration at the Beginining of the Twenty-First Century: Global Trends and Issues. International Social Science Journal, 52(165), 269-281. doi:10.1111/14682451.00258

Colaizzi, P. F. (1978). Psychological research as the phenomenologist views it.

Creswell, J. (2009). Research design: Qualitative, quantitative, and mixed methods approaches: SAGE Publications, Incorporated.

Crotty, M. (1998). The foundations of social research: Meaning and perspective in the research process: Sage.

Currie, S. (2016). Migration, work and citizenship in the enlarged European Union: Routledge. 
Devine, F., Baum, T., Hearns, N., \& Devine, A. (2007). Cultural diversity in hospitality work: the Northern Ireland experience. The International Journal of Human Resource Management, 18(2), 333-349.

Faraday, A., \& Plummer, K. (1979). Doing life histories. The Sociological Review, 27(4), 773-798.

Fontana, A., \& Frey, J. (2003). The Interviews: From Structured Questions to Negotiated Texts. IN Denzin, NK \& Lincoln, YS (Eds.) Collecting and Interpreting Qualitative Materials. Thousan Oaks. In: CA, Sage.

Germeten, S. (2007). Personal Narratives in Life History Research. Scandinavian Journal of Educational Research, 57(6), 612-624. doi:10.1080/00313831.2013.838998

ILO. (2005). Human Trafficking and Forced Labour Exploitation: Guidance for Legislation and Law Enforcement (922117347X). Retrieved from Geneva:

Janta, H., Ladkin, A., Brown, L., \& Lugosi, P. (2011). Employment experiences of Polish migrant workers in the UK hospitality sector. Tourism Management, 32(5), 1006-1019. doi:http://dx.doi.org/10.1016/j.tourman.2010.08.013

Kelly, P., \& Lusis, T. (2006). Migration and the transnational habitus: evidence from Canada and the Philippines. Environment and planning A, 38(5), 831-847.

Krasulja, N., Blagojevic, M. V., \& Radojevic, I. (2016). Brain-drain-The positive and negative aspsects of the phenomenon. Scientifica Review article, 62 (3), 131-142.

Lewis, H., Dwyer, P., Hodkinson, S., \& Waite, L. (2015). Hyper-precarious lives: Migrants, work and forced labour in the Global North. Progress in Human Geography, 39(5), 580-600.

Lincoln, Y. S., \& Guba, E. G. (1985). Naturalistic inquiry (Vol. 75): Sage.

Lucas, R., \& Mansfield, S. (2010). The Use of Migrant Labour in the Hospitality Sector: Current and Future Implications. In M. Ruhs \& B. Anderson (Eds.), Who Needs Migrant Workers?: Labour shortages, immigration, and public policy. Oxford.

Lumsden, K., \& Winter, A. (2014). Reflexivity in criminological research. In Reflexivity in Criminological Research (pp. 1-19): Springer.

Mayaka, M. A., \& Prasad, H. (2012). Tourism in Kenya: An analysis of strategic issues and challenges. Tourism Management Perspectives, 1, 48-56. doi:http://dx.doi.org/10.1016/j.tmp.2011.12.008

McCollum, D., \& Findlay, A. (2018). Oiling the wheels? Flexible labour markets and the migration industry. Journal of Ethnic and Migration Studies, 44(4), 558-574. doi:10.1080/1369183X.2017.1315505 
McDowell, L., Batnitzky, A., \& Dyer, S. (2009). Precarious work and economic migration: emerging immigrant divisions of labour in Greater London's service sector. International Journal of Urban and Regional Research, 33(1), 3-25.

Migration and Remittances Factbook. (2016). The International Bank for Reconstruction and Development. Retrieved from Washington, DC.https://siteresources.worldbank.org/INTLAC/Resources/Factbook2011Ebook.pdf.Accessed $1^{\text {st }}$ November 2019

Mooney, S. K., Harris, C., \& Ryan, I. (2016). Long hospitality careers-a contradiction in terms? International Journal of Contemporary Hospitality Management, 28(11), 2589-2608.

Morgan, G., \& Smircich, L. (1980). The case for qualitative research. Academy of management Review, $5(4), 491-500$.

Munck, R. (2010). Slavery: exception or rule? In Human Trafficking in Europe:Character,Cases and Consequence (pp. 17-29). Basingtoke: Palgrave Macmillan.

Ngoma, A. L., \& Ismail, N. W. (2013). The Determinants of brain drain in developing countries. International Journal of Social Economics, 40(8), 5-5.

Okello, M. (2014). Economic contribution, challenges and way forward for wildlife-based tourism industry in Eastern African countries. Journal of Tourism and Hospitality, 3(1).

Okoth, K. (2003). Kenya: What role for diaspora in development. Retrieved from https://www.migrationinformation.org./article/kenya-what-role-diaspora-development. Accessed $1^{\text {st }}$ November 2019

Rienzo, C. (2016). Migrants in the UK labour market: An overview. Migration Observatory Briefing, 6th Revision. Oxford: COMPAS.

Robinson, R. N. (2013). Darker still: Present-day slavery in hospitality and tourism services. Hospitality \& Society, 3(2), 93-110.

Robinson, R. N., Martins, A., Solnet, D., \& Baum, T. (2019). Sustaining precarity: critically examining tourism and employment. Journal of Sustainable Tourism, 27(7), 1008-1025.

Shaw, R. (2010). Embedding reflexivity within experiential qualitative psychology. Qualitative research in psychology, 7(3), 233-243. $++$

Sindiga, I. (1994). Employment and training in tourism in Kenya. Journal of tourism studies, 5(2), 4552.

Spencer, L., Ritchie, J., Ormston, R., O'Connor, W., \& Barnard, M. (2003). Analysis;Principles and processes. In J. Ritchie, J. Lewis, M. Carol, \& O. Rachel (Eds.), Qualitative research practice: A guide for social science students and researchers (pp. 269-290): Sage. 
UN. (2004). United Nations convention against transnational organized crime and the protocols thereto. Retrieved from New York:

Weinberg, D. (2002). Qualitative research methods: Blackwell publishers Malden, MA.

World Bank. (2016). Taking on Inequality: Poverty and shared propserity. Retrieved from https://openknowled ge.worldbank.org/bitstream/handle/10986/25078/9781464809583.pdf. Accessed $1^{\text {st }}$ November 2019

Wu, B., Guo, L., \& Sheehan, J. (2010). Employment Conditions of Chinese Migrant Workers in the East Midlands: A Pilot Study in a Context of Economic Recession (9221236943). Retrieved from International Labour office for China and Mongolia: 